\title{
GAS FLARING IN THE NIGER DELTA OF NIGERIA: A VIOLATION OF THE RIGHT TO LIFE AND COMMENT ON THE CASE OF JOHNAH GBEMRE V SHELL PETROLEUM DEVELOPMENT COMPANY OF NIGERIA LIMITED
}

\author{
Abdulkadir Bolaji Abdulkadir*
}

\begin{abstract}
The relationship between the protection of the environment and human rights was first established in the Stockholm Declaration of 1972. Since then, it has become acknowledged that human rights such as the right to life can only be enjoyed in a pollution free environment. It is on this premise that this paper seeks to examine how gas flaring, being one of the major environmental challenges in the Niger Delta, is affecting the right to life of the inhabitants. Materials are sourced from both primary and secondary sources to analyse the issues in contention. Data and information are extracted from the Amnesty International Report, United Nations Environmental Programme Report, and the United Nations Development Programme Report. Also, an analysis of the case of Johnah Gbemre $v$ Shell Petroleum Development Company Of Nigeria Limited is done in order to evaluate the judicial response on this perspective.
\end{abstract}

Keywords: Nigeria, Niger Delta, gas flaring, oil companies, and the right to life.

LLB, BL, LLM, PhD (IIUM Malaysia), Lecturer, Department of Public Law, Faculty of Law, University of Ilorin, Nigeria. E-mail: barristeraba01@yahoo.com. 


\title{
PEMBAKARAN GAS DI DELTA NIGER, NIGERIA: PENCABULAN HAK UNTUK HIDUP DAN ULASAN \\ KE ATAS KES JOHNAH GBEMRE V SHELL PEMBANGUNAN SYARIKAT PETROLEUM NIGERIA LIMITED
}

\begin{abstract}
ABSTRAK
Hubungan antara perlindungan alam sekitar dan hak asasi manusia telah mula diwujudkan pada Pengisytiharan Stockholm 1972. Sejak itu, ia telah diakui bahawa hak asasi manusia seperti hak untuk hidup hanya boleh dinikmati dalam persekitaran yang bebas dari pencemaran alam sekitar. Berlandaskan penyataan tersebut, kertas kerja ini bertujuan untuk mengkaji bagaimana pembakaran gas, sebagai salah satu daripada cabaran alam sekitar yang utama di Delta Niger, menjejaskan hak untuk hidup bagi penduduk di situ. Oleh itu, dalam menganalisa isu-isu yang menjadi pertikaian, bahan-bahan kajian adalah diperolehi daripada sumber-sumber utama dan sekunder. Dalam kajian ini, data-data dan maklumat telah diambil dari Amnesty International Report, United Nations Environmental Programme Report, dan United Nations Development Programme Report. Selain itu, kes Johnah Gbemre v Shell Petroleum Development Company Of Nigeria Limited juga dianalisa bagi menilai maklumbalas kehakiman dalam perspektif ini.
\end{abstract}

Kata kunci: Nigeria, Delta Niger, pembakaran gas, syarikat-syarikat minyak, hak untuk hidup.

\section{INTRODUCTION}

The discovery and extraction of natural resources has brought different consequences to countries endowed with such resources. While some of these nations have become economically strong and self-sustaining, 
the reverse is the case in other nations. ${ }^{1}$ When oil was first discovered in the Niger Delta, there was justifiably so much hopefulness and confidence that it would be a basis of huge development for the country. ${ }^{2}$ As years passed by, the expectation is no longer encouraging and the communities in the Niger Delta have been suffering from continuous gas flaring since the commencement of oil exploration and this has scored very low on the United Nation's Human Development Index. ${ }^{3}$ Gas flaring has done enormous damage to the natural environment because it has led to pollution of the essential elements of the environment (air, water, and land). ${ }^{4}$ Consequently, a number of basic human rights are increasingly being put at risk. ${ }^{5}$ This is because the right to life can be affected by pollution of

$1 \quad$ See UNEP, Environmental Assessment of Ogoni Land, UNEP, 2011, 311. See also Wahab Egbewole, "Millennium Development Goal and the Niger-Delta," The Jurist, A Publication of the Law Students' Society, University of Ilorin (2006): 36; Aluko M.A.O., "Sustainable Development, Environmental Degradation and the Entrenchment of Poverty in the Niger Delta of Nigeria" Kamla-Raj J. Hum. Ecol 15, No.1 (2004): 63-68; "Defining an Environmental Strategy for the Niger Delta," World Bank, accessed February 21, 2014, http://wwwwds.worldbank. org/servlet $/$ main?menuPK=64187510\&page $\mathrm{PK}=64193027 \& \mathrm{piPK}=$ 64187937\&theSitePK=523679\&entityID =000094946_00082605382641.

$2 \quad$ See Francis O. Adeola, "Environmental Injustice and Human Rights Abuse: The States, MNCs and Repression of Minority Groups in the World," Human Ecology Review 8, No. 1 (2001): 39; Gurr, Ted. R. "Why Minorities Rebel: A global Analysis of Communal Mobilization and Conflict Since 1945," IPSR 14 (1993): 161-201.

3 See UNDP, Niger Delta Human Development Report, 2006, 1-6.

$4 \quad$ See for example, United Nations Environmental Programme, "Global Environment Outlook," UNEP, 2007, 1-3; United Nations, "Resilient People, Resilient Planet: A Future Worth Choosing," United Nations, 2012, 1-5; World Commission on Environment and Development, Our Common Future, From One Earth to One World, WCED, 1987, 4-8.

$5 \quad$ See Human Rights Council, Report of the United Nations High Commissioner for Human Rights on Analytical study on the relationship between human rights and the environment, Human Rights Council, 2011, 6-14. For more discussion on this see: Vibhute K.I., "Environment, Present and Future Generations: Inter-Generational Equity, Justice and Responsibility," Indian J.Int'l L 38 (1998): 65-73; Midgley, "The End of Anthropocentrism" in Attfield and Belsey (eds.), 
the environment and cultural rights endangered by interference in the land of the community. ${ }^{6}$

As environmental awareness grows, there has been a better appreciation that the continued existence and development of humankind and the enjoyment of human rights are dependent on a healthy environment. ${ }^{7}$ It is on this premise that this paper examines how environmental pollution is affecting the right to life of the people of Niger Delta. The Niger Delta is faced with numerous environmental problems such as oil spillage, gas flaring, seismic survey, dredging and many others. However, the focus of this paper will be limited to gas flaring. This paper is divided into five major parts, this introduction being the first part. The second part discusses the term 'gas flaring' and its impact on the Niger Delta. The third part examines the impact of gas flaring on the enjoyment of the basic right to life. To achieve this, the paper relies heavily on judicial interpretations of some notable jurisdictions. The fourth part analyses the judicial response to gas flaring in Nigeria, and the last part presents the conclusion.

Philosophy and the Natural Environment Royal, Institute of Philosophy Supplement No. 36, 1994, 111; Symonides J., "The Human Right to a Clean Balanced and Protected Environment," Int'l J. Of Legal Information 20, No.1 (1992): 24-40 at 29; Contra Downs J.A., "A Healthy and Ecologically Balanced Environment: An Argument for a Third Generation Right" Duke J. Comp. \& Int'l L 3 (1993): 351-385.

6 UNEP, "Human Rights and the Environment: the Joint Report OHCHR and UNEP," United Nations Environmental Programme, 2004, 8-17. For more discussion, see: Anderson, M.R. and Ahmed A., "Assessing Environmental Damage under Indian Law," RECIEL 5, No. 4 (1996), 335-341; Anderson, M.R., "International Environmental Law in Indian Courts" (1998) 7(1) RECIEL 7, No.1 (1998): 22-31; Jariwala, C.M., "A Judicial Approach in the Fire Works Noise Pollution: A Critical Overview," All Indian Reporter Journal Section (1999): 72-74; La Vina A.G.M., "The Right to a Sound Environment in the Philippines: The Significance of the Minors Oposa Case," RECIEL 3, No. 4 (1994): 246252; Sachs Aron, "Upholding Human Rights and Environmental Justice," In L. Starke (ed.), State of the World (New York: W.W. Norton and Company, 1996), 131.

See principle 1 of the Stockholm Declaration 1972. 


\section{GAS FLARING IN THE NIGER DELTA}

The Niger Delta is metaphorically regarded as the Middle East of Nigeria because of its oil and ecological abundances. ${ }^{8}$ There are closely between 250 and 300 diverse tribal communities in Nigeria, sixty of which reside in the Niger Delta. The Niger Delta covers 75,000 square miles and 185 local government areas. ${ }^{9}$ The region is regarded as third among the world's largest swamp forest and rich in ecological varieties. ${ }^{10}$ These ecological varieties and other resources in the Niger Delta are being threatened due to environmental problems arising from the activities of oil industries. ${ }^{11}$ The Niger Delta is faced with various environmental challenges with their concomitant impact on the enjoyment of basic human rights such as the right to life, health, property to mention but few. Some of these degrading challenges include: oil spills, gas flaring, dredging, seismic activities, and construction activities.

Gas flaring has been a touchy issue in Nigeria since the commencement of oil operations in the Niger Delta. The gas that is flared is referred to as associated gas. ${ }^{12}$ Such gases are produced during the oil production process. ${ }^{13}$ There are three major ways by which the

$8 \quad$ United Nations Development Programme, Niger Delta Human Development Report, UNDP, 2006, 1-2.

$9 \quad$ Ibid.

10 The Niger Delta consists of nine out of 36 states making up the Federal Republic of Nigeria. They are: "Abia, Akwa-Ibom, Bayelsa, Cross-River, Delta, Edo, Imo, Ondo and River States." The population of the nine states is said to be nearly 28-30 million, one third of whom resides in the three main oil-producing states. It is a region of many ethnic and linguistic pluralities, majorly comprising of five ethnic groups. These are: the Ijaw, Yoruba, Edo, Igbo and Delta Cross.

11 United Nations Development Programme, Niger Delta Human Development Report, UNDP, 2006, 4-11.

12 Ike Okonta and Oronto Douglas, Where the Vultures Feast: Shell, Human Rights and Oil in the Niger Delta, San Francisco: Sierra Club Books, 2001, p. 209. Human Rights Watch Reports, The Warri Crisis: Fuelling Violence, December, 2003; Human Rights Watch Reports, The Niger Delta: No Democratic Dividends, October 2002.

13 Eferiekosa Ukala "Gas Flaring in Nigeria's Niger Delta: Failed Promises and Reviving Community Voices," Wash. \& Lee J. Energy, Climate \& Env't97, No. 2 (2011), 98-126. 
associated gas could be dispensed with. Firstly, if separated from the oil, it could be used as liquefied natural gas. ${ }^{14}$ Secondly, it could be re-injected into the soil to avoid its environmental impacts. Thirdly and which is prominent in the developing countries is to burn off or flare such gases. ${ }^{15}$ Thus, gas flaring refers to a situation whereby the gases from a petroleum product are allowed to be released into the atmosphere. ${ }^{16} \mathrm{By}$ this process, there will be pollution of the air and it is expected that some elements of green house effects will be a common phenomenon in an area where such gases are being flared. ${ }^{17}$ Owing to the untenable exploration practices coupled with the absence of gas utilisation infrastructure in Nigeria, the country flares more than 75 per cent of the gas it produces and re-injects only 12 per cent. ${ }^{18}$ It is estimated that more than two billion standard cubic feet of gas per day is currently being flared in the Niger Delta making it the highest in any member-nation of the Organisation of Petroleum Exporting Countries (OPEC). ${ }^{19}$

The flaring of associated gas is life threatening because of its adverse impacts on the life of the people. Given that the location of flares are very close to villages and communities, it has damaged vegetation as no vegetation can sustain the enormous heat produced by

\footnotetext{
$14 \quad$ Ibid.

15 United Nations Development Programme, Niger Delta Human Development Report, UNDP, 2006, 4-11.

16 See Hassan Tai Ejibunu, Nigeria's Niger Delta Crisis: Root Causes of Peacelessness, EPU Research Papers, EPU, Austria, 2007, 1-41; Kaniye SA Ebeku "The Right to a satisfactory Environment and the African Commission," African Human Rights Law Journal 3 (2003): 149; Patrick D. Okonmah "Right to a Clean Environment: The Case for the People of Oil-Producing Communities in the Nigerian Delta," Journal of African Law 41, No. 1 (1997): 43-67.

$17 \quad$ Nnimmo Bassey, "Gas Flaring: Assaulting Communities, Jeopardizing the World" (paper Presented at the National Environmental Consultation Organized by the Environmental Rights Action in Conjunction with the Federal Ministry of Environment held in Abuja between 10-11 December, 2008).

18 Amnesty international, Nigeria: Petroleum, Pollution and Poverty in the Niger Delta, (United Kingdom: Amnesty International Publications, 2009), 14-17.

$19 \quad$ Ibid.
} 
the flares of gas. ${ }^{20}$ Also, gas flaring has adverse effects on the life of the people as the environment continues to exude heat every time the gas is flared. This has resulted in cases of body rashes and ill health. ${ }^{21}$ It can even result in death depending on the level of exposure. ${ }^{22}$

\section{GAS FLARING AND THE RIGHT TO LIFE}

The realisation of the most basic human needs is dependent on numerous rudiments of the environment. We need air to breath, water to drink, food to eat and shelter for protection and the quality of the duty to protect life rests directly on the state. This duty entails the responsibility to prevent circumstances that might endanger human life. ${ }^{23}$ It follows therefore that this right is violated when environmental hazards are created by the activities of the state or entities under its jurisdiction. ${ }^{24}$ The state is not

$20 \quad$ Eregha P.B. and Irughe I.R., "Oil Induced Environmental Degradation in the Nigeria's Niger Delta: The Multiplier Effects," Journal of Sustainable Development in Africa 11, No. 4 (2009): 160-175; Frynas G.J., "Legal Change in Africa, Evidence from Oil-Related Litigation in Nigeria," Journal of African Law 43, No. 2 (1999): 128.

21 Amnesty international, Nigeria: Petroleum, Pollution and Poverty in the Niger Delta, (United Kingdom: Amnesty International Publications, 2009), 18.

22 Ohimain, E.I. "Environmental Impacts of Oil Mining Activities in the Niger Delta Mangrove Ecosystem" Proceedings of the International Mine Water Association (IMWA) 2003 Congress, Johannesburg, South Africa; Ohimain, E. I., "Preservation of Niger Delta Wetland Resources through Proper Handling and Rehabilitation of Abandoned Waste Sulfidic Dredge Spoils," in Environmental Science and Technology, ed. G. Uzochukwu, K. Schimmel, G. B. Reddy, S. H. Chang and V. Kabadi, (Columbus: Battelle Press, 2003b), 3-12; Ohimain, E. I., W. Andriesse and van M.E.F. Mensvoort "Environmental Impacts of Abandoned Dredged Soils and Sediments: Available Options for their Handling, Restoration and Rehabilitation," Journal of Soils and Sediments 2004, 59-65.

23 See Patrick D. Okonmah "Right to a Clean Environment: The Case for the People of Oil-Producing Communities in the Nigerian Delta," Journal of African Law 41, No. 1 (1997), 43-67.

24 See Cancado Trindade A.A., "The Parallel Evolutions of International 
only required to abstain from taking life deliberately, but also to take satisfactory measures to safeguard it. ${ }^{25}$ One of the rights recurrently infringed by incidents of oil pollution is the right to life. ${ }^{26}$ This right is recognised in both the constitution of a state and international human rights documents. For instance, the Universal Declaration provides that "everyone has the right to life, liberty and security of the person." 27 The International Covenant on Civil and Political Rights adds that "every human being has the inherent right to life... No one shall be arbitrarily deprived of his life." 28 The American Convention states that "every person has the right to have his life respected." ${ }^{29}$ The African Charter also provides in explicit terms that "human beings are inviolable. Every human being shall be entitled to respect for his life and the integrity of his person.

Human Rights Protection and Environmental Protection and the Absence of Restrictions upon the Exercise of Recognized Human Rights," in the Inter-American Institute of Human Rights Magazine, No. 13, January-June 1991; see also Human Rights and the Environment: Final Report Prepared by Mrs. Fatima Zohra Ksentini, Special Rapporteur, Pursuant to Sub-Commission Resolution 1993/32, UN ESCOR, Hum. Rts. Comm., Sub-Comm. On Prevention of Discrimination and Protection of Minorities, $46^{\text {th }}$ Sess., UN Doc. E/CN.4/Sub.2/1994/9 (1994), 44-45.

See Pathak R.S., "The Human Rights System as a Conceptual Framework for Environmental Law" in Edith Brown Weiss, Environmental Change and International Law: New Challenges and Dimensions, (Tokyo: UN University Press, 1992), 205-243 at 219.

Alexandre Kiss, Définition et nature juridique d'un droit de l'homme à l'environnement, en Environnement et droits de l'homme, Pascal Kromarek, directrice de publication, 1987; Michael J. Kane, "Promoting Political Rights to protect the Environment," The Yale Journal of International Law 18, No. 1, 389-390; Michael R. Anderson, "Human Rights Approaches to Environmental Protection: An Overview," in Human Rights Approaches To Environmental Protection, eds. Alan E. Boyle \& Michael R. Anderson, (Oxford: Clarendon Press, 1996), 1-4, 21-23. See article 3 of the Universal Declaration of Human Rights 1948. See article 6(1) of the International Covenant on Civil and Political Rights 1966. 
No one may be arbitrarily deprived of this right." ${ }^{30}$ The Constitution of the Federal Republic of Nigeria 1999 provides in section 33 that: ${ }^{31}$

"Every persons has a right to life, and no one shall be deprived intentionally of his life, save in execution of the sentence of a court in respect of a criminal offence of which he has been found guilty in Nigeria."

Owing to the sacredness of human life, most if not all Constitutions of the world recognise the duty to preserve human life. In this regard, therefore, environmental pollution poses a threat to human existence. Pollution of the different levels of environment may have far reaching effects on the lives of the people either directly or indirectly. Klaus Toepfer, Executive Director of the United Nations Environment Programme, mirrored this in his statement to the $5^{\text {th }}$ Session of the Commission on Human Rights in 2001 when he said that: ${ }^{32}$

"Human rights cannot be secured in a degraded or polluted
environment. The fundamental right to life is threatened
by soil degradation and deforestation and by exposures
to toxic chemicals, hazardous wastes and contaminated
drinking water. Environmental conditions clearly help to
determine the extent to which people enjoy their basic
rights to life, health, adequate food and housing, and
traditional livelihood and culture. It is time to recognize
that those who pollute or destroy the natural environment
are not just committing a crime against nature, but are
violating human rights as well."

Virtually all the constitutions of states and international treaties on human rights contain explicit provisions on the right to life. It is apparent that this right imposes a positive duty on states not to take life deliberately or carelessly. In this context, the right to life is far beyond physical killing

\footnotetext{
$30 \quad$ See article 4 of the African Charter on Human and Peoples Rights 1981.

$31 \quad$ See section 33(1) of the Constitution of Federal Republic of Nigeria 1999 [as amended in 2011].

$3257^{\text {th }}$ session of the Commission on Human Rights, 2001.
} 
whether intentional or accidental. It requires the prevention of any activities likely to endanger life and this involves the protection of the environment from pollution..$^{33}$ Thus, the right to life goes beyond a simple prohibition not to take life and includes some optimistic commitment on the state to take steps on activities likely resulting in loss of life or affecting life expectancy. ${ }^{34}$ In this perspective, the right to life has been interpreted to include: the right to continue to exist as a human being, the right to benefit from quality of life, and the right to means of livelihood. ${ }^{35}$ It is therefore incumbent on the state to regulate activities likely to endanger the life of its citizens, especially the indigenous people who carry the proportionate burden of environmental abuse. ${ }^{36}$ The right to life also implies the right to live in a healthy environment. That is, an environment where pollution is under control. For instance, in the case of General Secretary, West Pakistan Salt Miners Labour Union (CBA) Khewara, Jhelum v The Director, Industries and Mineral Development, ${ }^{37}$ the Pakistani

$33 \quad$ Fawcett, "The Application of the European Convention on Human Rights," (1969) quoted in Desgagne, "International Environmental Values into the European Convention on Human Rights," AJIL 89 (1995), 263-294.

Abdul Hasseb Ansari, "Right to a Healthful Environment As a Means to Ensure Environmental Justice: An Overview with Specific Reference to India, Philippines and Malaysia," MLJA 4 (1998): 25; Ainul Jaria Maidin, "Environmental Protection in the Land Planning System in Malaysia: A Study of the Legal Control Measures" (PhD Diss, University Wales, 2004) 261.

35 See the following cases: Charan Lal Sahu v Union of India [1990] AIR SC 1480; Subash Kumar v State of Bihar [1991] 1 SCC 598; State of Punjab v Ram Lubhaya Bagga [1998] 4 SCC 117; Kirloskar Bros Ltd v ESI Corporation [1996] 2 SCC 682; Pakistan Chest Foundation v Government of Pakistan [1997] CLC 1379.

36 M.R. Anderson, and Ahmed A., "Assessing Environmental Damage under Indian Law," RECIEL 5, No. 4 (1996): 335-341; Anderson, M.R., "International Environmental Law in Indian Courts," RECIEL 7, No. 1 (1998): 22-31; C.M Jariwala, "A Judicial Approach in the Fire Works Noise Pollution: A Critical Overview," All Indian Reporter Journal Section (1999): 72-74; La Vina A.G.M., "The Right to a Sound Environment in the Philippines: The Significance of the Minors Oposa Case," RECIEL 3, No. 4 (1994): 246-252.

37 [1994] SCMR 2061. 
Court considered the extent of the application of the right to life contained in article 9 of the Constitution. In this case, the petitioner sought to enforce the right of the residents to have clear and unpolluted water on the ground that if the miners were allowed to continue their activities which were extended in the water catchment area, the watercourse, reservoir and the pipelines would get contaminated. The court held that contamination of the water system constituted a serious threat to human life and existence. The Court gave a broad interpretation to the word 'life' and stated that:

\begin{abstract}
"The word 'life'...cannot be restricted to a vegetative life or mere anima existence. In hilly area where access to water is scare, difficult or limited, the right to have water free from pollution and contamination is a right to life itself. This does not mean persons residing in another part of the country where water is in abundance, does not have such right. The right to have unpolluted water is the right to every person wherever he lives." ${ }^{38}$
\end{abstract}

Gas flaring in the Niger Delta occurs day after day and this continues to damage the people's source of livelihood and pollutes the air and water used for drinking and other domestic uses. At present, no one can say when the oil companies will put an end to flaring of gases in the region. This has had unimaginable consequences on the peoples' right to life. For instance, findings have shown that exposure to gas flaring has led to a series of health problems in the Niger Delta ranging from respiratory problems, to lung cancer and birth defects; thereby endangering the life of the inhabitants. ${ }^{39}$ This is confirmed from the statement of Amnesty International that: ${ }^{40}$

"For many years, residents of the Niger Delta have complained that gas flares seriously damages their quality

\footnotetext{
$38 \quad$ Ibid.

39 See the United Nations Development Programme, Niger Delta Human Development Report, UNDP, 2007.

40 Amnesty International, Petroleum, Pollution and Poverty in the Niger Delta, (United Kingdom: Amnesty International, 2009), 17-19.
} 
of life and pose a risk to their health. Flares which continues for 24 hours a day in many areas, cause serious problems and discomfort for people living near the sites where flaring occurs.... while there is no direct evidence of impacts of gas flares on pregnant women, they are more likely to be vulnerable to any airborne contaminants during this period and exposure to oil-related contamination have been shown be linked to maternal outcomes such as spontaneous abortion in other settings."

A Report by the American Central Intelligence Agency (CIA) revealed that "everyday, eight million cubic feet of natural gas are burned off in flares that light the skies across the Niger Delta, not even driving off $5 \mathrm{cms}$, hunting not only fisheries and poisoning the agriculture, but contributing to global warming." Also, a statement by MOSOP (Movement for the Survival of Ogoni People) on the effect of gas flaring on the people of Niger Delta further shows how it is affecting the life of the people. It reads: ${ }^{41}$ "The once beautiful Ogoni countryside is no more a source of fresh air and green vegetation. All one sees and feels around is death." ${ }^{\prime 2}$ It is therefore submitted that gas flaring is life threatening and a serious environmental hazard with far reaching effects on the lives of the people of the Niger Delta. Thus, the protection of the right to life is beyond physical murder or manslaughter. It entails every situation that may affect the quality of life.

\section{COMMENT ON THE CASE OF JOHNAH GBEMRE V SHELL PETROLEUM DEVELOPMENT COMPANY OF NIGERIA LIMITED. ${ }^{43}$}

In the Niger Delta where environmental pollution is largely rampant, the all persuading influence of the oil industries and the bigoted approach of the judges to environmental cases have made access to environmental

\footnotetext{
$41 \quad$ Ken Saro-Wiwa "They are killing my People," in Ogoni's Agonies. ed. Na'Allah (Trenton: Africa World Press), 329-359.

$42 \quad$ Ibid.

43 Suit No. FHC/CS/B/153/2005 [Unreported].
} 
justice a daunting task. The Nigerian judiciary has been impassive in giving orders mandating companies whose activities are damaging the environment to cease the actions complained of or to take preventive measures in the mitigation of their operative impacts. The contemplation of the possible loss of income overshadows considerations for the protection of environment. This is due mostly to the fact that the Nigerian economy is dependent on the proceeds from the sale of crude oil.

Between 1990 and 2004, there have been numerous oil related cases instituted in the Nigerian courts complaining pollution from oil exploration, loss of income, loss of property, contamination of drinking water leading to water borne diseases and so on in the cases of Shell $v$. Tiebo VII, ${ }^{44}$ Shell v. Isaiah, ${ }^{45}$ Seismograph Services v. Mark, ${ }^{46}$ Ogiale v. Shell, ${ }^{47}$ and Shell v. Ambah. ${ }^{48}$ The general feature that flows through all these cases are: they are all claims for compensation for the operation of oil companies in their local communities, they are regularly oil spillage claims for loss of income from fishing and farming, pollution of drinking water, damage to farmlands and crops, and damage to health as a result of water-borne diseases. In all these cases, the courts did not make an order for the remediation of damage done to the natural environment, the land, and water resources. On the contrary, in the case of Shell v. Farah, ${ }^{49}$ apart from asking for compensation, the plaintiffs purposely asked the court to make an order for the remediation of the polluted environment. The court was innovative in coming to a decision in this case and unlike other oil spillage cases in Nigeria where conflicting expert evidence is given for both parties, the court resolved the case by assigning two independent experts to help the court in reaching a decision whether the polluted land had been remediated to its pre-impact conditions. Shell v. Farah laid the foundation for transformation as it is the first case where apart from the award of compensation, the court ordered remediation of the damaged land.

\begin{tabular}{ll}
\hline 44 & (2005) 3-4 S.C. \\
45 & (2001) 11 N.W.L.R. (Part 723) 168. \\
46 & {$[1993] 7$ N.W.L.R. 203. } \\
47 & [1997] 1 N.W.L.R. (Pt 480) 148. \\
48 & (1991) 3 N.W.L.R. (Part 593) 1. \\
49 & (1995) 3 N.W.L.R. (Pt 382) P. 148.
\end{tabular}


The recent case of Johnah Gbemre $v$ Shell Petroleum Development Company of Nigeria Limited ${ }^{50}$ shows the willingness of the Nigerian judiciary to construe the constitutional right to life lengthily to include the right to a healthy/clean environment. The order of the Federal High Court on the $14^{\text {th }}$ of November 2005 symbolised a significant turning point in the great effort by local communities in the Niger Delta to save from harm their health, environment and their farmlands, and to put an end to gas flaring. In this case, that Mr. Gbemre in a representative capacity for himself and for each and every member of the Iwehereken community in Delta State Nigeria filed a case against Shell Nigeria, Nigerian National Petroleum Corporation (NNPC) and the Attorney General of the Federation. The Applicants sought the following reliefs from the court: ${ }^{51}$

1. A declaration that the constitutionally guaranteed fundamental rights to life and dignity of human persons provided in sections 33(1) and 34(1) of the Constitution of the Federal Republic of Nigeria, 1999 and reinforced by Articles 4, 16 and 24 of the African Charter on Human and Peoples Rights (Ratification and Enforcement) Act, Cap. A9, Vol. 1, Laws of the Federation of Nigeria, 2004 inevitably includes the right to a clean, poisonfree, pollution-free and healthy environment.

2. A declaration that the actions of the first and second defendants violate the applicants who have the right to respect of their lives and dignity of their persons and to enjoy the best attainable state of physical and mental health as well as right to a general satisfactory environment favourable to their development.

3. A declaration that the failure of the first and second defendants to carry out environmental impact assessment in the applicant's community concerning the effects of their gas flaring activities is a violation of section 2(2) of the Environmental Impact Assessment Act, Cap. E12, Vol. 6, Laws of the Federation of Nigeria, 2004 and contributed to the violation of the applicant's said fundamental rights to life and dignity of human persons.

\footnotetext{
50 Suit No. FHC/CS/B/153/2005 [Unreported].

$51 \quad$ Ibid.
} 
4. A declaration that the provisions of section 3(2) (a) (b) of the Associated Gas Re-Injection Act, Cap. A25, Vol. 1, Laws of the Federation of Nigeria, 2004 and section 1 of the Associated Gas Re-Injection (Continued Flaring of Gas) Regulations S.1. 43 of 1984 under which continued flaring of gas in Nigeria may be allowed are inconsistent with the applicant's rights to life and/or dignity of human persons enshrined in sections 33(1) and 34(1) of the Constitution of the Federal Republic of Nigeria, 1999 and Articles 4, 16 and 24 of the African Charter on Human and Peoples Rights (Ratification and Enforcement) Act, Cap. A9, Vol. 1, Laws of the Federation of Nigeria, 2004 and are therefore unconstitutional, null and void by virtue of section 1(3) of the same Constitution.

5. AN ORDER of perpetual injunction restraining the first and second defendants by themselves or by their agents, servants, contractors or workers or otherwise howsoever from further flaring of gas in the applicant's said community.

The court declared that the actions of the first and second respondents in continuing to flare gas in the course of their oil exploration and production activities in the applicants' community is a violation of the fundamental right to life (including healthy environment) and dignity of human persons guaranteed by the Constitution and the African Charter. The court further declared that the first and second respondents; Shell Nigeria and NNPC were to be restrained from further flaring of gas in the applicant $\mathrm{s}$ community and were to take instantaneous measures to end the further flaring of gas in the applicant's community. The Court made the following declaratory order:

1. That the constitutionally guaranteed fundamental rights to life and dignity of human persons provided by Sections 33(1) and 34(1) of the Constitution of the Federal Republic of Nigeria, 1999 and reinforced by Art. 4, 16 and 24 of the African Charter on Human Procedure Rules (Procedure and Enforcement) Act Cap A9 Vol.1 Laws of the Federation of Nigeria, 2004 inevitably includes the right to a clean poison-free, pollution free and healthy environment. 
2. That the actions of the $1^{\text {st }}$ and $2^{\text {nd }}$ Respondent in continuing to flare gas in the course of their oil exploration and production activities in the Applicant s community is a violation of their fundamental right to life (including healthy environment) and dignity of human persons guaranteed by the Constitution and the African Charter.

3. That the provisions of Section 3(2)(a) and (b) of the Associated Gas Reinjection Act, Cap A25 Vol. 1, Laws of the Federation of Nigeria 2004 and Section 1 of the Associated Gas Reinjection (continued flaring of gas) Regulations Section 1.43 of 1984 under which the continued flaring of gas in Nigeria maybe permitted are inconsistent with the Applicant s Right to life and/or dignity of human person enshrined in the constitution and the African Charter and are therefore unconstitutional, null and void by virtue of Section 1(3) of the Nigerian Constitution.

The case of Gbemre v. Shell ${ }^{52}$ is a celebrated case in Nigeria because it is the first judicial authority to declare that gas flaring is illegal, unconstitutional, and a breach of the fundamental human right to life. This case is a clear indication that a healthy environment is fundamental to the realisation of basic human rights and is significant to Nigerians because of two reasons. First, it pictures how gas flaring constitutes a threat to the enjoyment of the right to life in the Niger Delta. This shows that matters concerning the protection of the environment can be brought under the purview of human rights. Secondly, the case also mirrored how the right to life has been expanded or interpreted in a wider perspective to include the protection of the environment and the enjoyment of a healthful environment. This is an indication that the existing human rights provisions in the Nigerian Constitution can go a long way to foster the right to a healthful environment. Thus, since environmental problems can affect the enjoyment of basic human rights, there is therefore nothing inconsistent in bringing environmental matters under the umbrella of human rights. 


\section{CONCLUSION}

As discussed in this paper, the flaring of natural gas from oil fields as a by-product of crude oil production is a regular occurrence that dominates the skyline in the Niger Delta. It is the most noticeable consequence of the oil industry on daily life. The available data shows that more gas is flared in Niger Delta of Nigeria than anywhere else in the world and this has positioned Nigeria as one of the world's biggest gas flarer. Consequently, basic human rights such as the right to life which is the focus of discussion is being endangered by the flare of gases. In this context, the right to life is far beyond protection against physical killing whether intentionally or accidentally. It includes protection from activities likely to endanger life such as gas flaring. This therefore imposes a positive obligation on the Nigerian Government to ensure adequate control and regulation of gas flaring, being one of the major activities affecting life. The Government must not also permit private entities such as oil industries in the Niger Delta to conduct their activities in a way to imperil life. Additionally, the case of Gbemre v. Shell ${ }^{53}$ examined in this paper is an eye opener to the people of the Niger Delta in particular and Nigerians as a whole because it shows that the constitutionally guaranteed rights such as the right to life could be invoked against those causing environmental pollution. Therefore, this is an indication that protected rights in the Nigerian Constitution could be a means of securing adequate remedy in cases of environmental pollution in Nigeria.

53 Ibid. 